\title{
PENDIDIKAN MULTIKULTURAL Upaya Membangun Keberagamaan Inklusif di Sekolah
}

\author{
Husniyatus Salamah Zainiyati*
}

\begin{abstract}
A bstract: Indonesia, with its diverse social, cultural and geographical variety, is one of the biggest multicultural societies in the world. This diversity -when misused- can cause many problems such as corruption, collusion, nepotism, poverty, violence, damage to environment, separatism, and human right violation. Vis-à-vis this, multicultural education suggests that diversity of ethnicity, culture, language, religion, society, gender, intellectual acumen and age can in fact be used to create inclusive pluralism through sufficient strategy and efficient concept of education. In practical terms, what is required from a teacher in this whole concept of education is not only to be able to teach his/her subject matter, but also to implant the multicultural and inclusive values such as democracy, humanism, and pluralism. In the end, what this approach can achieve is to produce the out-put that has not only the academic skill in his/her specialization, but also the ability to adopt and apply the norms of pluralism which will lead him/her to be more tolerant and understanding toward diversity and differences.
\end{abstract}

Keywords: multicultural education, inclusive diversity, the PAI subject

\section{Pendahuluan}

Praktek kekerasan yang mengatas-namakan agama, dari fundamentalisme, radikalisme, hingga terorisme, akhir-akhir ini semakin marak di tanah air. Kesatuan dan persatuan bangsa saat ini sedang diuji eksistensinya. Berbagai indikator yang memperlihatkan adanya tanda-tanda perpecahan bangsa, dengan transparan mudah kita baca. Konflik di Ambon, Papua, maupun Poso, seperti api dalam sekam, sewaktu-waktu bisa meledak, walaupun berkali-kali bisa diredam. Peristiwa tersebut, bukan saja telah banyak merenggut korban jiwa, tetapi juga telah menghancurkan ratusan tempat ibadah (baik masjid maupun gereja).

Bila kita amati, agama seharusnya dapat menjadi pendorong bagi umat manusia untuk selalu menegakkan perdamaian dan meningkatkan kesejahteraan bagi seluruh umat di bumi ini. Namun, realitanya agama justru menjadi salah satu penyebab terjadinya kekerasan dan kehancuran umat manusia. ${ }^{1}$ Oleh karena itu, diperlukan upaya-upaya preventif agar masalah pertentangan agama tidak akan terulang lagi di masa yang akan datang. Misalnya, dengan mengintensifkan forum-fo rum dialog antar umat beragama dan aliran kepercayaan (dialog antar iman), membangun pemahaman keagamaan yang lebih pluralis dan inklusif, dan memberikan pendidikan tentang pluralisme dan toleransi beragama melalui sekolah (lembaga pendidikan). ${ }^{2}$

Pada sisi yang lain, pendidikan agama yang diberikan di sekolah-sekolah pada umumnya

\footnotetext{
*Fakultas Tarbiyah IAIN Sunan Ampel Surabaya

${ }^{1}$ Kasus-kasus pertentangan antar-agama juga banyak terjadi di seluruh belahan dunia. Misalnya, di Bosnia Herzegovina, Muslim dan Katolik saling membunuh. Di Irlandia Utara, umat Kristen dan Katolik saling bermusuhan hingga kini. Di Timur Tengah, meskipun tidak disebabkan perbedaan agama, akan tetapi yang bersitegang justru mewakili tiga golongan masyarakat yang berbeda agama, Islam, Yahudi dan Kristen, dan sebagainya. Baca, Nur Achmad (ed.), Pluralitas Agama Kerukunan dalam Keragaman (J akarta: PT. G ramedia, 2001), 88.

2 M. Ainul Yaqin, Pendidikan Multikultural Cross-C ultural Understanding untuk Demokrasi dan Keadilan (Yogyakarta: Pilar M edia, 2005), 35.
} 
juga tidak menghidupkan pendidikan multikultural yang baik, bahkan cenderung berlawanan. A kibatnya konflik sosial sering kali diperkeras oleh adanya legitimasi keagamaan yang diajarkan dalam pendidikan agama di sekolah-sekolah daerah yang rawan konflik. $\mathrm{H}$ al ini membuat konflik mempunyai akar dalam keyakinan keagamaan yang fundamental sehingga konflik sosial kekerasan semakin sulit diatasi, karena dipahami sebagai bagian dari panggilan agamanya. ${ }^{3}$

Realita tersebut menunjukkan bahwa pendidikan agama baik di sekolah umum maupun sekolah agama lebih bercorak eksklusif, yaitu agama diajarkan dengan cara menafikan hak hidup agama lain, seakan-akan hanya agamanya sendiri yang benar dan mempunyai hak hidup, sementara agama yang lain salah, tersesat dan terancam hak hidupnya, baik di kalangan mayoritas maupun minoritas. Seharusnya pendidikan agama dapat dijadikan sebagai wahana untuk mengembangkan moralitas universal yang ada dalam agama-agama sekaligus mengembangkan teologi inklusif dan pluralis. Berkaitan dengan hal ini, maka penting bagi institusi pendidikan dalam masyarakat yang multikultur untuk mengajarkan perdamaian dan resolusi konflik seperti yang ada dalam pendidikan multikultural

\section{Pendidikan Muktikultural}

Akar pendidikan multikultural, berasal dari perhatian seorang pakar pendidikan Amerika Serikat, Prudence Crandall (18-3-1890) yang secara intensif menyebarkan pandangan tentang arti penting latar belakang peserta didik, baik ditinjau dari aspek budaya, etnis, dan agamanya. Pendidikan yang memperhatikan secara sungguh-sungguh latar belakang peserta didik merupakan cikal bakal bagi munculnya pendidikan multikultural. ${ }^{4}$

Secara etimologi istilah pendidikan multikultural terdiri dari dua term, yaitu pendidikan dan multikultural. Pendidikan berarti proses pengembangan sikap dan tata laku seseorang atau kelompok dalam usaha mendewasakan melalui pengajaran, pelatihan, proses dan cara mendidik. Dan multikultural diartikan sebagai keragaman kebudayaan, aneka kesopanan.

Sedangkan secara terminologi, pendidikan multikultural berarti proses pengembangan seluruh potensi manusia yang menghargai pluralitas dan heterogenitasnya sebagai konsekwensi keragaman budaya, etnis, suku dan aliran (agama). Pengertian seperti ini mempunyai implikasi yang sangat luas dalam pendidikan, karena pendidikan dipahami sebagai proses tanpa akhir atau proses sepanjang hayat. Dengan demikian, pendidikan multikultural menghendaki penghormatan dan penghargaan setinggi-tingginya terhadap harkat dan martabat manusia. ${ }^{5}$

Konsep pendidikan multikultural dalam perjalanannya menyebar luas ke kawasan di luar AS khususnya di negara-negara yang memiliki keragaman etnis, rasionalisme, agama dan budaya seperti di Indonesia. Sedangkan wacana tentang pendidikan multikultural, ${ }^{6}$ secara sederhana

\footnotetext{
3 Musa Asy'arie, "Pendidikan Multikultural dan Konflik Bangsa”, Kompas, 3 September 2004, 5. Baca juga, Syamsul Ma'arif, Pendidikan Pluralisme di Indonesia (Yogyakarta: Logung Pustaka, 2005), 87-98.

${ }^{4}$ Muhaemin Al-Ma'hady, "Multikulturalisme dan Pendidikan Multikultural" dalam http://artikel.us/muhaemin 604.html, 27 Mei 2004, 3.

${ }^{5}$ Ainurrofiq Dawam, "Emoh" Sekolah Menolak "Komersialisasi Pendidikan" dan "Kanibalisme Intelektual", Menuju Pendidikan Multikultural (Yogyakarta: INSPEAL Press, 2003), 100-101.

${ }^{6}$ Secara generik, pendidikan multikultural memang merupakan sebuah konsep yang dibuat dengan tujuan untuk menciptakan persamaan peluang pendidikan bagi semua siswa yang berbeda-beda rasionalisme, etnis, kelas sosial dan kelompok budaya.
} 
dapat didefinisikan sebagai "pendidikan untuk/tentang keragaman kebudayaan dalam meresponi perubahan demografis dan kultural lingkungan masyarakat tertentu atau bahkan dunia secara keseluruhan".?

$\mathrm{Hal}$ ini sejalan dengan pendapat Paulo Freire, pendidikan bukan merupakan "menara gading" yang berusaha menjauhi realitas sosial dan budaya. Pendidikan menurutnya, harus mampu menciptakan tatanan masyarakat yang terdidik dan berpendidikan, bukan sebuah masyarakat yang hanya mengagungkan prestise sosial sebagai akibat kekayaan dan kemakmuran yang dialaminya. ${ }^{8}$ Pendidikan multikultural (multicultural education) merupakan respon terhadap perkembangan keragaman populasi sekolah, sebagaimana tuntutan persamaan hak bagi setiap kelompok. Dan secara luas pendidikan multikultural itu mencakup seluruh siswa tanpa membedakan kelompok-kelompoknya seperti gender, etnik, ras, budaya, strata sosial dan agama.

Selanjutnya J ames Bank, ${ }^{9}$-salah seorang pioner dari pendidikan multikultural dan telah membumikan konsep pendidikan multikultural menjadi ide persamaan pendidikan- mengatakan bahwa substansi pendidikan multikultural adalah pendidikan untuk kebebasan (as education for freedom) sekaligus sebagai penyebarluasan gerakan inklusif dalam rangka mempererat hubungan antar sesama (as inclusive and cementing movement).

Mengenai fokus pendidikan multikultural, Tilaar mengungkapkan bahwa dalam program pendidikan multikultural, fokus tidak lagi diarahkan semata-mata kepada kelompok rasial, agama dan kultural domain atau mainstream. Fokus seperti ini pernah menjadi tekanan pada pendidikan interkultural yang menekankan peningkatan pemahaman dan toleransi individu-individu yang berasal dari kelompok minoritas terhadap budaya mainstream yang dominan, yang pada akhirnya menyebabkan orang-orang dari kelompok minoritas terintegrasi ke dalam masyarakat mainstream. Pendidikan multikultural sebenarnya merupakan sikap "peduli" dan mau mengerti (difference), atau "politics of recognition" politik pengakuan terhadap orang-orang dari kelompok minoritas. ${ }^{10}$

Melihat dan memperhatikan pengertian pendidikan multikultural di atas, dapat diambil beberapa pemahaman, antara lain; pertama, pendidikan multikultural merupakan sebuah proses pengembangan yang berusaha meningkatkan sesuatu yang sejak awal atau sebelumnya sudah ada. Karena itu, pendidikan multikultural tidak mengenal batasan atau sekat-sekat sempit yang sering menjadi tembok tebal bagi interaksi sesama manusia; kedua, pendidikan multikultural mengembangkan seluruh potensi manusia, meliputi; potensi intelektual, sosial, moral, religius, ekonomi, potensi kesopanan dan budaya. Sebagai langkah awalnya adalah ketaatan terhadap nilai-nilai luhur kemanusiaan, penghormatan terhadap harkat dan martabat seseorang, penghargaan terhadap orang-orang yang berbeda dalam hal tingkatan ekonomi, aspirasi politik, agama, atau tradisi budaya. Ketiga, pendidikan yang menghargai pluralitas dan heterogenitas. Pluralitas dan heterogenitas adalah sebuah keniscayaan ketika berada pada masyarakat sekarang ini. Dalam hal ini, pluralitas bukan hanya dipahami keragaman etnis dan suku, akan tetapi juga

\footnotetext{
7 Muhaemin Al-Ma'hady, “Multikulturalisme..., 2.

${ }^{8}$ Paulo Freire, Pendidikan Sebagai Praktek Pembebasan, terj. Alois A. N ugroho (J akarta: Gramedia, 1984), 34.

${ }^{9}$ Paul G orski, Multicultural Philosophy Series, Part 1: A B rief H istory of Multicultural Education (The McG raw-Hill Companies, 2003), 1.

${ }^{10}$ Tilaar, H .A.R, Perubahan Sosial dan Pendidikan: Pengantar Pedagogik Transformatif untuk Indonesia (J akarta: Grasindo, 2002), 51-52.
} 
dipahami sebagai keragaman pemikiran, keragaman paradigma, keragaman paham, keragaman ekonomi, politik dan sebagainya. Sehingga tidak memberi kesempatan bagi masing-masing kelompok untuk mengklaim bahwa kelompoknya menjadi panutan bagi pihak lain. Dengan demikian, upaya pemaksaan tersebut tidak sejalan dengan nafas dan nilai pendidikan multikultural. Keempat, pendidikan yang menghargai dan menjunjung tinggi keragaman budaya, etnis, suku dan agama. Penghormatan dan penghargaan seperti ini merupakan sikap yang sangat urgen untuk disosialisasikan. Sebab dengan kemajuan teknologi telekomunikasi, informasi dan transportasi telah melampaui batas-batas negara, sehingga tidak mungkin sebuah negara terisolasi dari pergaulan dunia. Dengan demikian, privilage dan privasi yang hanya memperhatikan kelompok tertentu menjadi tidak relevan. Bahkan bisa dikatakan "pembusukan manusia" oleh sebuah kelompok. ${ }^{11}$

Dalam konteks itu, pendidikan multikultural melihat masyarakat secara lebih luas. Berdasarkan pandangan dasar bahwa sikap "indiference" dan "non-recognition" tidak hanya berakar dari ketimpangan struktur rasial, tetapi paradigma pendidikan multikultural mencakup subyek-subyek mengenai ketidak-adilan, kemiskinan, penindasan dan keterbelakangan kelompok-kelompok minoritas dalam berbagai bidang: sosial, budaya, ekonomi, pendidikan dan lain sebagainya. Paradigma seperti ini akan mendorong tumbuhnya kajian-kajian tentang 'ethnic studies" untuk kemudian menemukan tempatnya dalam kurikulum pendidikan sejak dari tingkat dasar sampai perguruan tinggi. Tujuan inti dari pembahasan tentang subyek ini adalah untuk mencapai pemberdayaan (empowerment) bagi kelompok-kelompok minoritas dan disadventaged.

Secara garis besar, paradigma pendidikan multikultural diharapkan dapat menghapus streotipe, sikap dan pandangan egoistik, individualistik dan eksklusif di kalangan anak didik. Sebaliknya, dia senantiasa dikondisikan ke arah tumbuhnya pandangan komprehensif terhadap sesama, yaitu sebuah pandangan yang mengakui bahwa keberadaan dirinya tidak bisa dipisahkan atau terintegrasi dengan lingkungan sekeliling yang realitasnya terdiri atas pluralitas etnis, rasionalisme, agama, budaya, dan kebutuhan. Oleh karena itu, cukup proporsional jika proses pendidikan multikultural diharapkan membantu para siswa dalam mengembangkan proses identifikasi (pengenalan) anak didik terhadap budaya, suku bangsa, dan masyarakat global. Pengenalan kebudayaan maksudnya anak dikenalkan dengan berbagai jenis tempat ibadah, lembaga kemasyarakatan dan sekolah. Pengenalan suku bangsa artinya anak dilatih untuk bisa hidup sesuai dengan kemampuannya dan berperan positif sebagai salah seorang warga dari masyarakatnya. Sementara lewat pengenalan secara global diharapkan siswa memiliki sebuah pemahaman tentang bagaimana mereka bisa mengambil peran dalam percaturan kehidupan global yang dia hadapi.

\section{Urgensi Pendidikan Multikultural di Indonesia}

Sebagaimana diketahui bahwa model pendidikan di Indonesia terbagi menjadi dua, yaitu pendidikan agama dan pendidikan nasional. Pendidikan yang ada sekarang ini cenderung

${ }^{11}$ Ainurrofiq Dawam, "Emoh" Sekolah ..., 101-103. 
menggunakan meto de kajian yang bersifat dikotomis. Maksudnya, pendidikan agama berbeda dengan pendidikan nasional. Pendidikan agama lebih menekankan pada disiplin ilmu yang bersifat normatif, establish, dan jauh dari realitas kehidupan. Sedangkan pendidikan nasional lebih cenderung pada akal atau inteligensi. Oleh karena itu, sangat sulit menemukan sebuah konsep pendidikan yang benar-benar komprehensif dan integral.

Salah satu faktor munculnya permasalahan itu adalah adanya pandangan yang berbeda tentang hakikat manusia. Kuatnya perbedaan pandangan terhadap manusia menyebabkan timbulnya perbedaan yang makin tajam dalam dataran teoritis, dan lebih tajam lagi pada taraf operasional. Fenomena tersebut, menjadi semakin nyata ketika para pengelola lembaga pendidikan memiliki sikap fanatisme yang sangat kuat, dan mereka beranggapan bahwa paradigmanya yang paling benar dan pihak yang lain salah, sehingga harus diluruskan. ${ }^{12}$

Manusia dan pendidikan adalah dua hal yang tidak dapat dipisahkan. Manusia sepanjang hidupnya melaksanakan pendidikan. Bila pendidikan bertujuan membina manusia yang utuh dalam semua segi kemanusiaannya, maka semua segi kehidupan manusia harus bersinggungan dengan dimensi spiritual (teologis), moralitas, sosialitas, emosionalitas, rasionalitas (intelektualitas), estetis dan fisik. Namun realitanya, proses pendidikan kita masih banyak menekankan pada segi kognitif saja, apalagi hanya nilai-nilai ujian yang menjadi standar kelulusan, sehingga peserta didik tidak berkembang menjadi manusia yang utuh. A kibat selanjutnya akan terjadi beragam tindakan yang tidak baik seperti yang akhir-akhir ini terjadi: tawuran, perang, penghilangan etnis, ketidak-adilan, kesenjangan ekonomi, korupsi, ketidak-jujuran, dan sebagainya.

Berdasarkan kenyataan tersebut, maka keberadaan pendidikan multikultural sebagai strategi pendidikan yang diaplikasikan pada semua jenis mata pelajaran, dengan cara menggunakan perbedaan-perbedaan kultural yang ada pada siswa sangat diperlukan, dengan pertimbangan sebagai berikut:

1. Pendidikan multikultural secara inheren sudah ada sejak bangsa Indonesia ada. Falsafah bangsa Indonesia adalah suka gotong royong, membantu, menghargai antara suku dan lainnya.

2. Pendidikan multikultural memberikan secercah harapan dalam mengatasi berbagai gejolak masyarakat yang terjadi akhir-akhir ini. Keberhasilan pendidikan dengan mengabaikan ideologi, nilai-nilai, budaya, kepercayaan dan agama yang dianut masing-masing suku dan etnis harus dibayar mahal dengan terjadinya berbagai gejolak dan pertentangan antar etnik dan suku. Salah satu penyebab munculnya gejolak seperti ini, adalah model pendidikan yang dikembangkan selama ini lebih mengarah pada pendidikan kognitif intelektual dan keahlian psikomotorik yang bersifat teknis semata. Padahal kedua ranah pendidikan ini lebih mengarah kepada keahlian yang lepas dari ideologi dan nilai-nilai yang ada dalam tradisi masyarakat, sehingga terkesan monolitik berupa nilai-nilai ilmiah akademis dan teknis empiris. Sementara menurut pendidikan multikultural, adalah pendidikan yang senantiasa menjunjung tinggi nilai-nilai keyakinan, heterogenitas, pluralitas agama apapun aspeknya dalam masyarakat.

3. Pendidikan multikultural menentang pendidikan yang berorientasi bisnis. Pendidikan yang

12 Ibid., 63-64. 
diharapkan oleh bangsa Indonesia sebenarnya bukanlah pendidikan ketrampilan semata, melainkan pendidikan yang harus mengakomodir semua jenis kecerdasan, yang sering disebut kecerdasan ganda (multiple intelligence). Menurut H oward Gardner, kecerdasan ganda yang perlu dikembangkan secara seimbang adalah kecerdasan verbal linguistic, kecerdasan logika matematika, kecerdasan yang terkait dengan spasial ruang, kecerdasan fisik kinestetik, kecerdasan dalam bidang musik, kecerdasan yang terkait dengan lingkungan alam, kecerdasan interpersonal dan kecerdasan intrapersonal. J adi, jika ketrampilan saja yang dikembangkan maka pendidikan itu jelas berorientasi bisnis.

4. Pendidikan multikultural sebagai resistensi fanatisme yang mengarah pada jenis kekerasan. Kekerasan muncul ketika saluran perdamaian sudah tidak ada lagi. ${ }^{13}$

Dengan demikian, pendidikan multikultural sekaligus untuk melatih dan membangun karakter siswa agar mampu bersikap demokratis, humanis, dan pluralis di lingkungan mereka.

\section{Membangun Keberagaman Inklusif di Sekolah}

Di era multikulturalisme dan pluralisme, pendidikan agama sedang mendapat tantangan karena ketidak-mampuannya dalam membebaskan peserta didik ke luar dari eksklusifitas beragama. Wacana kafir-iman, muslim non-muslim, surga-neraka seringkali menjadi bahan pelajaran di kelas selalu diindoktrinasi.

Pelajaran teologi diajarkan sekedar untuk memperkuat keimanan dan pencapaiannya menuju surga tan pa dibarengi dengan kesadaran berdialog dengan agama-agama lain. Kondisi inilah yang menjadikan pendidikan agama sangat eksklusif dan tidak toleran. Padahal di era pluralisme dewasa ini, pendidikan agama mesti melakukan reorientasi filosofis paradigmatik tentang bagaimana membangun pemahaman keberagamaan peserta didik yang lebih inklusifpluralis, multikultural, humanis, dialogis-persuasif, kontekstual, substantif dan aktif sosial.

Paradigma keberagamaan yang inklusif-pluralis berarti menerima pandapat dan pemahaman lain yang memiliki basis ketuhanan dan kemanusiaan. Pemahaman keberagamaan yang multikultural berarti menerima adanya keragaman ekspresi budaya yang mengandung nilai-nilai kemanusiaan dan keindahan. Pemahaman yang humanis adalah mengakui pentingnya nilai-nilai kemanusiaan dalam beragama, artinya seorang yang beragama harus dapat mengimplementasikan nilai-nilai kemanusiaan; menghormati hak asasi orang lain, peduli terhadap orang lain dan berusaha membangun perdamaian bagi seluruih umat manusia.

Paradigma dialogis-persuasif lebih mengedepankan dialog dan cara-cara damai dalam melihat perselisihan dan perbedaan pemahaman keagamaan dari pada melakukan tindakantindakan fisik seperti teror, perang, dan bentuk kekerasan lainnya. Paradigma kontekstual berarti menerapkan cara berpikir kritis dalam memahami teks-teks keagamaan. Paradigma keagamaan yang substantif berarti lebih mementingkan dan menerapkan nilai-nialai agama dari pada hanya melihat dan mengagungkan simbol-simbol keagamaan. Sedangkan paradigma pemahaman keagamaan aktif sosial berati agama tidak hanya menjadi alat pemenuhan kebutuhan rohani secara pribadi saja. Akan tetapi yang terpenting adalah membangun kebersamaan dan solidaritas

${ }^{13}$ Imam Machalli dan Musthofa, Pendidikan Islam dan Tantangan G lobalisasi (Yogyakarta: Ar-Ruzz, 2004), 278-279. 
bagi seluruh manusia melalui aksi-aksi sosial yang nyata yang dapat meningkatkan kesejahteraan umat manusia. ${ }^{14}$

Dengan membangun paradigma pemahaman keberagmaan yang lebih humanis, pluralis, dan kontekstual diharapkan nilai-niali universal yang ada dalam agama sepeti kebenaran, keadilan, kemanusiaaan, perdamaian dan kesejahteraan umat manusia dapat ditegakkan. Lebih khusus lagi, agar kerukunan dan kedamaian antar umat bergama dapat terbangun.

Contoh kasus yang berakaitan dengan problematika keberagamaan di sekolah dan bagaimana peran guru/dosen dalam membangun pemahaman keberagamaan yang inklusisf pada siswa:

"Beberapa bulan setelah kasus pemboman dua buah kafe di kota A, seorang guru, setelah membaca berita di media massa, bercerita tentang kasus tersebut di depan murid-muridnya. Dia bercerita bahwa apa yang telah dilakukan oleh B dan kawan-kawan adalah bagian dari jihad. Dia menambahkan bahwa apa yang dilakukan B cs, menurut agama, tidak berdosa telah melakukan tindakan tersebut karena para korban adalah orang kafir yang beragama C yang sedang senang-senang di sebuah kafe".

Penjelasan guru atau dosen seperti ini, tentunya sangat menyesatkan bagi peserta didiknya. Guru dalam kisah tersebut, telah menumbuhkan sikap permusuhan terhadap pemeluk agama $\mathrm{C}$, dan telah melegalkan tindakan kekerasan terhadap orang lain (umat beragama lain). Dalam hal ini, seharusnya guru menjelaskan bahwa tindakan B dan kawan-kawan tidak bisa dibenarkan baik secara hukum maupun menurut agama. Dia juga harus menjelaskan bahwa semua agama atau kepercayaan yang ada di bumi ini, tidak pernah memerintahkan kepada pemeluknya untuk melakukan kekerasan terhdap siapa saja, termasuk pada pemeluk agama lain.

Mencermati gambaran peristiwa tersebut di atas, guru dan sekolah memegang peranan penting dalam mengimplementasikan nilai-nilai keberagamaan yang inklusif di sekolah, apabila guru mempunyai paradigma pemahaman keberagamaan yang inklusif, maka dia juga akan mampu mengajarkan dan mengimplementasikan nilai-nilai keberagamaan tersebut pada siswa di sekolah.

\section{Peran Guru dan Sekolah dalam Membangun Keberagamaan Inklusif di Sekolah}

Peran guru dalam hal ini meliputi; pertama, seorang guru/dosen harus mampu bersikap demokratis, baik dalam sikap maupun perkataannya tidak diskriminatif. Kedua, guru/dosen seharusnya mempunyai kepedulian yang tinggi terhadap kejadian-kejadian tertentu yang ada hubungannya dengan agama. Misalnya, ketika terjadi bom Bali (2003), maka seorang guru yang berwawasan multikultural harus mampu menjelaskan keprihatinannya terhadap peristiwa tersebut. Ketiga, guru/dosen seharusnya menjelaskan bahwa inti dari ajaran agama adalah menciptakan kedamaian dan kesejahteraan bagi seluruh umat manusia, maka pemboman, invasi militer, dan segala bentuk kekerasan adalah sesuatu yang dilarang oleh agama. Keempat, guru/ dosen mampu memberikan pemahaman tentang pentingnya dialog dan musyawarah dalam menyelesaikan berbagai permasalahan yang berkaitan dengan keragaman budaya, etnis, dan

${ }^{14}$ M. Ainurrofiq, Pendidikan Multikultural, 56-57. 
agama (aliran), misalnya, kasus penyerbuan dan pengusiran J amaah A hmadiyah di NTB tidak perlu terjadi, jika wacana inklusivisme beragama ditanamkan pada semua elemen masyarakat termasuk peserta didik.

Selain guru, sekolah juga memegang peranan penting dalam membangun lingkungan pendidikan yang pluralis dan toleran. Langkah-langkah yang dapat ditempuh antara lain; 1). Untuk membangun rasa saling pengertian sejak dini antara siswa-siswa yang mempunyai keyakinan berbeda, maka sekolah harus berperan aktif menggalakkan dialog antar-iman dengan bimbingan guru-guru dalam sekolah tersebut. Dialog antar-iman semacam ini merupakan salah satu upaya yang efektif agar siswa terbiasa melakukan dialog dengan penganut agama yang berbeda; 2 ). Hal yang paling penting dalam penerapan pendidikan multikultural yaitu kurikulum dan buku-buku pelajaran yang dipakai, dan diterapkan di sekolah. ${ }^{15}$

\section{Pengembangan Materi Pendidikan Agama Islam Berbasis Multikultural}

Dalam rangka membangun keberagamaan inklusif di sekolah ada beberapa materi pendidikan agama Islam yang bisa dikembangkan dengan nuansa multikultural, antara lain: Pertama, materi al-Qur'an, dalam menentukan ayat-ayat pilihan, selain ayat-ayat tentang keimanan juga perlu ditambah dengan ayat-ayat yang dapat memberikan pemahaman dan penanaman sikap ketika berinteraksi dengan orang yang berlainan agama, sehingga sedini mungkin sudah tertanam sikap toleran, inklusif pada peserta didik, yaitu a) materi yang berhubungan dengan pengakuan al-Q ur'an akan adanya pluralitas dan berlomba dalam kebaikan (QS: al-Baqarah/2: 148); b) Materi yang berhubungan dengan pengakuan koeksistensi damai dalam hubungan antar umat beragama (QS: al-Mumtahanah/60: 8-9); c) materi yang berhubungan dengan keadilan dan persamaan (QS: al-Nisał4: 135)

Kedua, materi fiqih, bisa diperluas dengan kajian fiqih siyasah (pemerintahan). Dari fiqih siyasah inilah terkandung konsep-konsep kebangsaan yang telah dicontohkan pada zaman Nabi, Sahabat ataupun khalifah-khalifah sesudahnya. Pada zaman Nabi misalnya, bagaimana Nabi Muhammad saw. mengelola dan memimpin masyarakat Madinah yang multi-etnis, multi-kultur, dan multi-agama. Keadaan masyarakat Madinah pada masa itu tidak jauh beda dengan masyarakat Indonesia, yang juga multi-etnis, multi-kultur, dan multi-agama. ${ }^{16}$

Ketiga, materi akhlak yang menfokuskan kajiannya pada perilaku baik-buruk terhadap Allah, Rasul, sesama manusia, diri sendiri, serta lingkungan, penting artinya bagi peletakan dasardasar kebangsaan. Sebab, kelanggengan suatu bangsa tergantung pada Akhlak, bila suatu bangsa meremehkan akhlak, punahlah bangsa itu. Dalam al-Qur'an telah diceritakan tentang kehancuran kaum Luth, disebabkan runtuhnya sendi-sendi moral. Agar pendidikan agama bernuansa multikultural ini bisa efektif, peran guru agama Islam memang sangat menentukan. Selain selalu mengembangkan metode mengajar yang variatif, tidak monoton. Dan yang lebih penting, guru agama Islam juga perlu memberi keteladanan.

\footnotetext{
${ }^{15}$ M. Ainul Yaqin, Pendidikan Multikultural, 61-63.

${ }^{16}$ Abd. Rahman Assegaf, Politik Pendidikan Nasional Pergeseran Kebijakan Pendidikan Agama Islam dari Praproklamasi ke Reformasi (Yogyakarta: Kurnia Kalam, 2005), 35.
} 
Keempat, materi Sejarah Kebudayaan Islam (SKI) yang bersumber pada fakta dan realitas historis dapat dicontohkan praktik-praktik interaksi sosial yang diterapkan Nabi Muhammad saw. ketika membangun masyarakat Madinah. Dari sisi historis proses pembangunan Madinah yang dilakukan $\mathrm{Nabi}$ ditemukan fakta tentang pengakuan dan penghargaan atas nilai pluralisme dan toleransi.

Agar pemahaman pluralisme dan toleransi dapat tertanam dengan baik pada peserta didik, maka perlu ditambahkan uraian tentang proses pembangunan masyarakat Madinah dalam materi "Keadaan Masyarakat Madinah Sesudah Hijrah", dalam hal ini dapat ditelusuri dari Piagam Madinah. Sebagai salah satu produk sejarah umat Islam, Piagam Madinah merupakan bukti bahwa Nabi Muhammad berhasil memberlakukan nilai-nilai keadilan, prinsip kesetaraan, penegakan hukum, jaminan kesejahteraan bagi semua warga serta perlindungan terhadap kelompok minoritas. B eberapa ahli tentang sejarah Islam menyebut Piagam Madinah ${ }^{17}$ sebagai loncatan sejarah yang luar biasa.

Bila kita cermati, bunyi naskah konstitusi itu sangat menarik. la memuat pokok-pokok pikiran yang dari sudut tinjauan modern pun mengagumkan. Dalam konstitusi itulah pertama kalinya dirumuskan ide-ide yang kini menjadi pandangan hidup modern di dunia, seperti kebebasan beragama, hak setiap kelompok untuk mengatur hidup sesuai dengan keyakinannya, kemerdekaan hubungan ekonomi antar golongan dan lain-lain.

Menurut Nurcholish Madjid, toleransi merupakan persoalan ajaran dan kewajiban melaksanakan ajaran itu. J ika toleransi menghasilkan adanya tata cara pergaulan yang "enak" antara berbagai kelompok yang berbeda-beda, maka hasil itu harus dipahami sebagai "hikmah" atau "manfaat" dari pelaksanaan suatu ajaran yang benar. Hikmah atau manfaat itu adalah sekunder nilainya, sedangkan yang primer adalah ajaran yang benar itu sendiri. Sebagai sesuatu yang primer, toleransi harus dilaksanakan dan diwujudkan dalam masyarakat, sekalipun untuk kelompok tertentu - untuk diri sendiri- pelaksanaan toleransi secara konsekwen itu mungkin tidak menghasilkan sesuatu yang "enak". ${ }^{18}$

Materi-materi yang bersumber pada pesan agama dan fakta yang terjadi di lingkungan sebagai diuraikan di atas merupakan kisi-kisi minimal dalam rangka memberikan pemahaman terhadap keragaman umat manusia dan untuk memunculkan sikap positif dalam berinteraksi dengan kelompok-kelompok yang berbeda. Dalam proses pendidikan, materi itu disesuaikan dengan tingkatan dan jenjang pendidikan. Maksudnya, sumber bacaan dan bahasa yang digunakan disesuaikan dengan tingkat intelektual peserta didik di masing-masing tingkat

${ }_{17}$ Prinsip-prinsip Piagam Madinah, antara lain: Prinsip penggantian ikatan kesukuan dengan ikatan Islam. Dikatakan bahwa "orang-orang 1). Muslim dan Mukmin adalah umat yang satu dan antara mereka dan non muslim adalah juga umat yang satu, 2). Prinsip persatuan dan persaudaraan. 3). Prinsip persamaan. 4). Prinsip kebebasan. 5). Prinsip tolong menolong dan membela yang teraniaya. 6). Prinsip hidup bertetangga. 7). Prinsip keadilan. 8). Prinsip musyawarah. 9). Prinsip pelaksanaan hukum dan sanksi hukum. 10). Prinsip kebebasan beragama, dan hubungan antar pemeluk agama (hubungan antar bangsa/international). 11). Prinsip pertahanan dan perdamaian. 12). Prinsip amar ma'ruf dan nahi munkar. 13). Prinsip kepemimpinan. 14). Prinsip tanggung-jawab pribadi dan kelompok. 15). Prinsip ketaqwaan dan ketaatan (disiplin), lihat, Darwis Sadir, "Piagam Madinah", Al-Q anun: J urnal Pemikiran dan Pembaharuan Hukum Islam, Vo. 5, No. 1, J uni 2003, 252

${ }^{18}$ Nurcholish Madjid, "Masyarakat Madani dan Investasi Demokrasi: Tantangan dan Kemungkinan”, Republika, 10 Agustus 1999, 5. 
pendidikan. Untuk tingkat pendidikan lanjutan, materi dipilih dengan menyajikan fakta-fakta historis dan pesan-pesan al-Qur'an yang lebih konkrit serta memberikan perbandingan dan perenungan atas realitas yang sedang terjadi di masyarakat saat ini.

\section{Penutup}

Pendidikan multikultural kian mendesak untuk dilaksanakan di sekolah. Dengan pendidikan multikultural, sekolah menjadi lahan untuk menghapus prasangka, dan sekaligus untuk melatih dan membangun karakter siswa agar mampu bersikap demokratis, humanis dan pluralis.

Ada dua hal yang perlu dilakukan dalam pembangunan pendidikan multikultural di sekolah, yaitu; pertama, melakukan dialog dengan menempatkan setiap peradaban dan kebudayaan yang ada pada posisi sejajar. Kedua, mengembangkan toleransi untuk memberikan kesempatan masing-masing kebudayaan saling memahami. Toleransi di sini tidak hanya pada tataran konseptual, melainkan juga pada teknik operasionalnya.

\section{Daftar Rujukan}

Abd. Rahman, Assegaf. Politik Pendidikan Nasional Pergeseran Kebijakan Pendidikan Agama Islam dari Praproklamasi ke Reformasi. Yogyakarta: Kurnia Kalam, 2005.

Achmad, Nur (ed.). Pluralitas Agama Kerukunan Dalam Keragaman. J akarta: PT. G ramedia, 2001.

Ainul Yaqin, M. Pendidikan Multikultural Cross-Cultural Understanding untuk Demokrasi dan Keadilan, Yogyakarta: Pilar Media, 2005.

Asy'arie, Musa, "Pendidikan Multikultural dan Konflik Bangsa”, Kompas, 3 September 2004, 45.

Dawam, Ainurrofiq. "Emoh" Sekolah Menolak "Komersialisasi Pendidikan" dan "Kanibalisme Intelektual”, M enuju Pendidikan Multikultural. Yogyakarta: INSPEAL Press, 2003.

Freire, Paulo. Pendidikan Sebagai Praktek Pembebasan. terj. Alois A. Nugroho, Jakarta: Gramedia, 1984.

G orski, Paul. Multicultural Philosophy Series, Part 1: A Brief History of M ulticultural Education. The McG raw-Hill Companies, 2003.

H.A.R, Tilaar. Perubahan Sosial dan Pendidikan: Pengantar Pedagogik Transformatif untuk Indonesia. J akarta: G rasindo, 2002.

Ma'arif, Syamsul. Pendidikan Pluralisme di Indonesia. Yogyakarta: Logung Pustaka, 2005.

Machalli dan Musthofa, Imam. Pendidikan Islam dan Tantangan Globalisasi. Yogyakarta: ArRuzz, 2004.

Madjid, Nurcholish, "Masyarakat Madani dan Investasi Demokrasi: Tantangan dan Kemungkinan", Republika, 10 Agustus 1999, 4-5.

Muhaemin Al-Ma'hady, "Multikulturalisme dan Pendidikan Multikultural” dalam http://artikel.us/ muhaemin 6-04.html, 27 Mei 2004. 
Sadir, Darwis, "Piagam Madinah", Al-Q anun J urnal Pemikiran dan Pembaharuan Hukum Islam, Vo. 5, No. 1, J uni 2003, 250-257. 